\title{
O conceito de intervencionismo em Economia: uma análise discursiva a partir de artigos científicos
}

\author{
The concept of interventionism in Economy: a discursive analysis based on scientific articles
}

\author{
Isabel Cristina Pereira dos Santos \\ Mestre em Ciência da Informação \\ Universidade Federal do Rio Grande do Sul \\ isabel.pereira@ufrgs.br \\ Thiago Henrique Bragato Barros \\ Doutor em Ciência da Informação \\ Universidade Federal do Rio Grande do Sul \\ bragato.barros@ufrgs.br \\ Ivan Colangelo Salomão \\ Doutor em Economia \\ Universidade Federal do Paraná \\ ivansalomao@ufpr.br
}

\begin{abstract}
Resumo
Este artigo tem por objetivo identificar no discurso científico de alguns artigos publicados na Revista Análise Econômica no período 2015-2019 as colocações dos termos "intervenção" e "intervencionismo" em seus contextos, a fim de rastrear seus vieses ideológicos - se intervencionista ou liberal - por meio da Linguística de Corpus. A Linguística de Corpus é uma metodologia que se ocupa da coleta e exploração de uma grande quantidade de textos em formato eletrônico para fins de pesquisa linguística. Com o auxílio do gerenciador de corpus Sketch Engine, identificaram-se as ocorrências do termo "intervenção" e "intervencionismo". A análise dos dados foi realizada a partir de um referencial teórico da área de Economia e de Análise do Discurso no contexto da Ciência da Informação. Destaca-se que, no âmbito da Ciência da Informação, o levantamento de termos em seus contextos discursivos tem se mostrado imprescindível para a validação de conceitos em determinados domínios, visando ao aperfeiçoamento de Sistemas de Organização do Conhecimento. Para tanto, a Linguística de Corpus, como abordagem de corpus, e a Análise do Discurso, como metodologia de análise de textos científicos, têm contribuído para a Organização do Conhecimento, uma vez que, para que se elaborem sistemas de acesso à informação, além de tecnologia, é preciso entender a informação e seus múltiplos sentidos. O que se constatou nos artigos analisados foi um viés pró-intervencionismo.
\end{abstract}

\section{Palavras-chave}

Intervenção. Intervencionismo. Artigo científico. Linguística de Corpus. Análise do Discurso.

\section{Abstract}

This paper aims to identify in the scientific discourse of some articles published in Revista Análise Econômica in the period 2015-2019 the collocations of the terms "intervention" and "interventionism" in their contexts, in order to trace their ideological biases - whether interventionist or liberal through Corpus Linguistics. Corpus Linguistics is a methodology that deals with the collection and exploration of a large amount of texts in electronic format for the purposes of linguistic research. With the help of the Sketch Engine corpus manager, were identified occurrences of the terms "intervention" and "interventionism". Data analysis was carried out from a theoretical framework in the 
field of Economics and Discourse Analysis in the Information Science context. It is noteworthy that, in the scope of Information Science, the survey of terms in their discursive contexts has proved to be essential for the validation of concepts in certain domains, aiming at the improvement of Knowledge Organization Systems. Therefore, Corpus Linguistics, as a corpus approach, and Discourse Analysis, as a methodology for analyzing scientific texts, have contributed to the Knowledge Organization, since, in order to develop systems of access to information, in addition to of technology, it is necessary to understand information and its multiple meanings. What was found in what was said in the analyzed articles was a pro-interventionist bias.

\section{Keywords}

Intervention. Interventionism. Scientific article. Corpus Linguistics. Discourse Analysis.

\section{INTRODUÇÃO}

A intervenção estatal é assunto polêmico entre os analistas, sobretudo os economistas. A dicotomia intervencionismo/liberalismo tem sido analisada na literatura especializada há muito tempo, servindo de baliza para embasar o debate entre conservadores (neoliberais, neoclássicos, monetaristas) e progressistas (keynesianos, estruturalistas, neomarxistas, institucionalistas etc.) (BRESSER-PEREIRA, 1989). Sendo essa dicotomia uma questão instigante, este artigo busca compreender de que forma os autores de alguns artigos relacionados à temática intervencionismo, publicados na Revista Análise Econômica, se posicionam frente a esse conceito.

Por meio da análise do discurso, uma teoria dos sentidos, pretende-se identificar no discurso científico de alguns artigos publicados na Revista Análise Econômica, no período 2015-2019, as colocações dos termos "intervenção" e "intervencionismo" em seus contextos. Buscar-se-á, desse modo, rastrear seus vieses ideológicos - se intervencionista ou liberal - por meio da Linguística de Corpus, metodologia que se ocupa da coleta e exploração de uma grande quantidade de textos em formato eletrônico para fins de pesquisa linguística.

Visando a esse propósito, com o auxílio do gerenciador de corpus Sketch Engine, rastrearam-se, em um universo de 131 artigos, os que continham ocorrências dos termos "intervencionismo" e "intervenção". Desse rastreamento, 30 artigos apresentaram ocorrências para esses termos. Identificaram-se 109 ocorrências do termo "intervenção" e 27 ocorrências do termo "intervencionismo". O levantamento das colocações e de seus contextos possibilita a verificação de como os autores conceituam intervencionismo, e se esse conceito é expresso por uma perspectiva positiva ou negativa. A intenção é identificar os elementos ideológicos e históricos presentes na enunciação por meio das marcas do discurso e das formações discursivas à luz de autores da Análise do Discurso de corrente francesa, concebida por Michael Pêcheux nos anos 1960.

Para tanto, estruturou-se este artigo em seis seções, além desta breve introdução. $\mathrm{Na}$ seção 2, apresentam-se as considerações teóricas da Análise do Discurso à luz da argumentação de autores basilares, como Althusser, Pêcheux, Orlandi e Foucault, destacando-se o conceito de Ideologia e o discurso em artigos científicos, tendo por fundamento pesquisas realizadas no âmbito da Ciência da Informação. Na seção 3, estrutura-se o debate acerca de intervencionismo entre os economistas, segundo Lisboa e Pessoa (2016) e Bresser-Pereira (1989). Na seção 4, destacam-se os procedimentos que envolvem a Análise do Discurso e que irão norteá-la. Na seção 5, apresentam-se os resultados da pesquisa. Por fim, na seção 6 , tecem-se as considerações finais. 


\title{
2 ANÁLISE DO DISCURSO: CONSIDERAÇÕES TEÓRICAS
}

A Análise do Discurso se constituiu como disciplina na França no decorrer dos anos 1960, período de questionamentos e de desconstrução das teorias linguísticas, tomando forma a partir de discussões que envolviam a Linguística, o Marxismo e a Psicanálise, bem como das relações entre esses três domínios. Segundo Pêcheux (1999), naquele momento o efeito subversivo estruturalista ultrapassou os limites da produção teórica e das revistas especializadas das universidades, causando uma intervenção ideológica na literatura, influenciando, assim, o campo sociopolítico e dando origem a uma outra maneira de "ouvir" a política. Sobre a desconstrução das teorias linguísticas, Althusser, em Ler o Capital, reconhece que:

\begin{abstract}
A partir de Freud, começamos a suspeitar do que escutar, e, portanto, do que falar (e calar-se) quer dizer; que este "quer-dizer" do falar e do escutar descobre, sob a inocência da palavra e da escuta, a profundidade assinalável de um duplo fundo, o "quer-dizer" do discurso do inconsciente - este duplo fundo sobre o qual a linguística moderna, nos mecanismos da linguagem, pensa os efeitos e as condições formais. (ALTHUSSER, 1979/1980, p.14-15¹ apud PÊCHEUX, 1999, p. 29).
\end{abstract}

Althusser (1979/1980² apud PÊCHEUX, 1999), ao tratar sobre "o 'quer-dizer' do falar e do escutar", admite a existência de um duplo fundo no discurso, ou seja, de um texto para além do texto. A análise do discurso está além de uma análise semântica, pois possibilita transcender a estrutura profunda de um texto. Segundo Chomsky (2006), as regras que relacionam a estrutura profunda e a estrutura de superfície às representações de som e significado são as regras que foram dominadas pela pessoa que aprendeu um idioma. Elas constituem o seu conhecimento da língua; elas são usadas quando se fala e entende. Transcendendo o falar e o entender, está o discurso, que se constrói a partir da desnaturalização do texto, ou seja, a partir das informações extratextuais, da comparação do discurso com outros textos, da relação entre a memória interna e externa, do contexto histórico, das relações de poder, dos laços institucionais, que estão atrelados às formações ideológicas do sujeito discursivo.

Meurer (1997) apresenta uma concepção semelhante à descrita no parágrafo anterior ao diferenciar discurso de texto:

[...] o discurso é o conjunto de afirmações que, articuladas através da linguagem, expressam os valores e significados das diferentes instituições; o texto é a realização linguística na qual se manifesta o discurso. Enquanto o texto é uma entidade física, a produção linguística de um ou mais indivíduos, o discurso é o conjunto de princípios, valores e significados "por trás" do texto. (MEURER, 1997, p. 16, grifo do autor).

Já Orlandi (2009, p. 15), parafraseando Pêcheux, define discurso como "o homem falando" e "o efeito de sentidos entre os locutores". Nesse contexto, o discurso é dinâmico; é a "palavra em movimento". As relações da linguagem se dão pelas relações entre os sujeitos, os sentidos gerados por essas relações e seus efeitos na sociedade. Faz-se importante destacar a diferenciação que a autora coloca entre análise de conteúdo e análise de discur-

\footnotetext{
${ }^{1}$ ALTHUSSER, L. (1965). Lire Le Capital. Paris: Maspero, Tradução brasileira: Ler O Capital. Rio de Janeiro, RJ: Zahar, 1979/1980.

2 Ibidem.
} 
so, uma vez que ambas as metodologias podem confundir um analista principiante. Nesse sentido, argumenta a autora:

\begin{abstract}
A análise de conteúdo, como sabemos, procura extrair sentidos dos textos, respondendo à questão: o que este texto quer dizer? Diferentemente da análise de conteúdo, a Análise de Discurso considera que a linguagem não é transparente. Desse modo ela não procura atravessar o texto para encontrar um sentido do outro lado. A questão que ela coloca é: como este texto significa? [...] a questão a ser respondida não é o "o quê", mas o "como". Para responder, ela não trabalha com os textos apenas como ilustração ou como documento de algo que já está sabido em outro lugar e que o texto exemplifica. Ela produz um conhecimento a partir do próprio texto, porque o vê como tendo uma materialidade simbólica própria e significativa, como tendo uma espessura semântica: ela o concebe em sua discursividade. (ORLANDI, 2009, p. 17-18).
\end{abstract}

Ao se ler um texto tendo em mente a pergunta "o que este texto quer dizer?", a interpretação limitar-se-á ao nível semântico, provavelmente sem se cogitar a existência de um duplo fundo no discurso, nos termos mencionados por Althusser. No entanto, uma vez que se pergunta "como este texto significa?", manifesta-se a relação discursiva entre os sujeitos (enunciador-autor e receptor do discurso) e entre outros discursos (relações interdiscursos). Nota-se, então, o papel fundamental da leitura nessas duas esferas analíticas: o de se ler o sentido literal do texto e o de se extrair outros sentidos do mesmo. De acordo com Orlandi (2009), isso ocorre porque a linguagem não é transparente, ela é simbólica, carregada de sentidos. Dessas noções de leitura, surgem os conceitos de interpretação e de compreensão de texto.

Leffa (2012) argumenta que, na interpretação, o significado ocorre do objeto (texto) para o leitor; nesse caso, o leitor não pode atribuir significado ao objeto (texto), pois caracterizaria, nas palavras do autor, "uma impostura". A partir da etimologia do verbo "interpretar", o autor faz uma analogia esclarecedora entre a "arte da adivinhação" e a leitura para explicar o conceito desse verbo:

\footnotetext{
Etimologicamente a palavra "interpretar" vem do latim "interpes", que se referia à pessoa que examinava as entranhas de um animal para prever o futuro. Do ponto de vista da leitura, há um pressuposto interessante aqui: o significado daquilo que é lido não está na cabeça do interpres, do adivinho, mas contido no objeto. O interpres não pode atribuir um significado, não pode tirar algo de dentro de si para depositar no objeto; pode apenas extrair o significado que já está dentro do animal. Uma atribuição de sentido seria não só uma impostura, mas seria também negar ao interpres a capacidade de leitura; ele não inventa e nem cria, ele apenas reproduz o que supostamente preexiste na sua frente. Em suma, para o interpres, o significado emerge do próprio objeto em direção ao leitor (LEFFA, 2012, p. 260, grifo do autor).
}

No entanto, na compreensão, o percurso é inverso, pois o leitor traz o seu conhecimento de mundo para o texto, agregando a ele informações que propiciam a compreensão do mesmo. A esse respeito, Leffa (2012, p. 259) esclarece que "A compreensão, na acepção que se tenta definir aqui, não é uma ação consciente executada pelo leitor sobre um determinado objeto de leitura; é uma experiência que se vive abaixo da superfície da consciência, pela sua complexidade e pela rapidez com que acontece."

Tem-se, portanto, que interpretação e compreensão são conceitos que se distinguem, mas, ao mesmo tempo, se complementam. Para se chegar à compreensão, percorrese primeiro o caminho da interpretação: conectar seguimentos e enunciados, seus co-textos 
(as palavras em torno de um termo) e contextos (as orações em torno de um termo). No entanto, para alguns leitores, essa conexão pode ficar apenas no nível da interpretação do texto, sem que ele efetivamente acione mecanismos de compreensão, como a memória, os conhecimentos extratextuais, os conhecimentos de mundo etc., elementos que facilitariam a compreensão do tema.

Em um texto técnico-científico, por exemplo, caso o leitor desconheça a temática, as definições ou, até mesmo, o tecnoleto da área, a compreensão do texto restará prejudicada. Leffa (2012) explica que um leitor vazio não tem como retirar significado de um texto: "Se ele não trouxer esse conhecimento, não tem como estabelecer a conexão com os dados do texto; são dados que se perdem porque encontram uma memória vazia, sem possibilidade de encaixe, e consequentemente sem possibilidade de compreensão" (LEFFA, 2012, p. 258).

Em suma, o discurso se materializa no texto por meio de um conjunto de enunciados, que são partículas fundamentais de uma formação discursiva, uma vez que um enunciado pode se ligar a outro, formando uma rede de enunciados, para, dessa forma, produzir sentidos. A análise do discurso busca compreender de que maneira o texto, como objeto de estudo, produz esses sentidos, partindo de um sujeito para outro. Para tanto, o analista deve elaborar um dispositivo teórico próprio de interpretação, um método, fundamentado na teoria da Análise de Discurso, a fim de buscar compreender os sentidos que constituem o discurso; já para compreender esses sentidos, o analista não pode estar vazio, precisando dispor de conhecimentos extratextuais, de memória, da historicidade, do contexto social, entre outros fatores, para extrair os significados do texto.

\subsection{Discurso e Ideologia}

A partir do aprofundamento dos estudos sobre a linguagem, pesquisadores chegaram a um consenso de que ela não se restringe apenas à dimensão linguística - sintaxe, semântica e pragmática -, mas que abrange outras dimensões, como a cognitivista, a psicológica e a social. Essas três esferas são destacadas por Meurer (1997, p. 19) ao argumentar que a elaboração do discurso parte, primeiramente, de uma motivação, espontânea ou imposta, cuja origem pode ser individual ou institucional, formando uma representação mental dos fatos/realidade a que se quer referir. É um percurso de origem cognitivista/psicológica, em que representações mentais, intermediadas por formações ideológicas do sujeito discursivo, culminam em uma ação na sociedade. Daí a dimensão social do discurso.

No entendimento de Pêcheux (1999), todo discurso é inexoravelmente ideológico. Isso significa que nenhum discurso está imune à ideologia; a ideologia, porém, não é consciente, pois ela emerge do inconsciente e se manifesta na relação entre sujeito e linguagem, por meio da memória, da historicidade, do contexto social, das condições de existência do sujeito, materializando-se, assim, no discurso. Conforme a formação ideológica do sujeito que produz o discurso e do sujeito que o interpreta, o sentido do discurso pode ser alterado. Desse modo, todo discurso acaba tendo um efeito social em virtude de seu poder de persuasão, uma vez que exerce influência sobre o indivíduo e que busca hegemonia sobre outro discurso.

Em síntese, a ideologia é determinante na formação de sentidos de um discurso, que, para ser produzido, está condicionado ao contexto ideológico, ao contexto imediato e ao contexto histórico. O contexto imediato se faz presente durante a formulação do discurso, pelas circunstâncias da enunciação (ORLANDI, 2009, p. 30). Já o contexto histórico pode ser observado por meio de significados que ele produz e que remetem a períodos e fatos histó- 
ricos e a posicionamentos políticos. Ele está intimamente ligado à memória discursiva, que é a retomada do que já foi dito por alguém, em outro lugar e em outro momento. Nesse sentido, a memória discursiva é tratada como interdiscurso: "O interdiscurso disponibiliza dizeres que afetam o modo como o sujeito significa em uma situação discursiva dada." (ORLANDI, 2009, p. 31). O interdiscurso se refere, então, a outros dizeres que estão contidos no discurso e que são extraídos do discurso e são significados, ou ressignificados, pelo sujeito em uma determinada situação discursiva.

Para Foucault (2008), a noção de interdiscurso está incorporada à formação discursiva, conceito cunhado por ele na obra Arqueologia do Saber, ${ }^{3}$ publicada originalmente em 1969 , que manifesta a formação ideológica. A formação discursiva permite compreender as relações de sentido, que é, por sua vez, uma das condições de produção do discurso, em que um discurso sempre se relaciona com outro. É ela que determina o que o sujeito pode ou não dizer em uma dada formação ideológica, ou seja, a partir de sua posição em uma determinada conjuntura sócio-histórica (FOUCALT, 2008). Essa posição é evidenciada pelas marcas do discurso, as quais vinculam o discurso à ideologia do sujeito. Por meio das marcas do discurso pode-se depreender a posição ideológica do sujeito, se marxista ou liberal, por exemplo.

\subsection{O Discurso em Artigos Científicos}

Os discursos analisados neste estudo se materializam no gênero artigo científico, o qual se enquadra em um tipo textual dissertativo argumentativo, visando registrar e disseminar a produção científica de pesquisadores de determinado domínio do conhecimento. São discursos publicados em revistas científicas, produzidos por e para especialistas, geralmente elaboradas com vocabulário e linguagem específicos do domínio. No entanto, o discurso científico, sendo uma produção humana, não está isento de sofrer influências das condições do sujeito que o produz. Se, consoante Pêcheux (1999), todo discurso é ideológico, significa que nenhum discurso está imune à ideologia, inclusive o discurso científico, que se caracteriza como impessoal, objetivo e direto.

Segundo Demo (1995, p. 18), “A ciência está cercada de ideologia e senso comum, não apenas como circunstâncias externas, mas como algo que está já dentro do próprio processo científico, que é incapaz de produzir conhecimento puro, historicamente não contextuado." De acordo com o autor, sendo a ciência um fenômeno social, consequentemente a ideologia se faz presente na produção científica, a qual manifesta o posicionamento político do cientista. A produção intelectual do cientista também carrega consigo traços do seu conhecimento de mundo e da interpretação que ele faz desse mundo, que, mesmo de forma tênue, deixa marcas no discurso. Porém, a percepção dessa ideologia que se manifesta sutilmente não é um processo consciente; ela emerge do inconsciente e se manifesta na relação entre sujeito e linguagem, por meio do interdiscurso, da memória, da historicidade, do contexto social, das condições de existência do sujeito, tornando o sentido evidente e óbvio.

É nesse sentido que se pode afirmar que cada gênero discursivo se associa a épocas, a espaços e a regras específicas que regem o seu funcionamento. Segundo Cavalcante Filho (2010),

[...] há um jogo de regras, que controlam o funcionamento e a circulação dos discursos sociais. Por isso que não dizemos o que queremos, onde e quando quere-

\footnotetext{
${ }^{3}$ FOUCAULT, M. A arqueologia do saber. 7. ed. Rio de Janeiro: Forense Universitária, 2008.
} 
mos, mas os discursos são organizados socialmente, inserem-se numa ordem enunciativa e são regulados, moldados pelos gêneros que os constituem. Em outras palavras, cada esfera da comunicação social apresenta "tipos relativamente estáveis de enunciados" (CAVALCANTE FILHO, 2010, p. 761).

O jogo de regras que controla o funcionamento dos discursos científicos é definido pela comunidade científica, dentro das instituições acadêmicas - universidades e institutos de pesquisa. É essa congregação de atores que aceita ou não determinada pesquisa. Uma das formas de assentimento é a publicação de artigos em periódicos científicos, o que legitima a pesquisa e gera reconhecimento ao cientista frente a seus pares. 0 não enquadramento do discurso científico nesse jogo de regras institucionalizado - como, por exemplo, o plágio, a invenção ou o uso de dados não autorizados, entre outros - pode levar o pesquisador a sofrer advertências ou penalizações, restringindo a sua atuação no meio científico.

Os enunciados que moldam o discurso científico possuem uma característica própria do gênero artigo: a impessoalidade. Essa distinção possibilita ao sujeito certo afastamento das suas intenções comunicativas, atribuindo ao texto um caráter de cientificidade. Ela é evidenciada na forma como o enunciador-autor se coloca no texto, por meio de marcas do discurso, como o uso da voz passiva e da partícula "se", pela qual se indica a indeterminação do sujeito. Outra forma de impessoalidade dá-se pelo uso do plural majestático ou plural de modéstia, marcado no texto pelo uso da primeira pessoa do plural. Essa marcação cria uma aproximação entre sujeito e leitor, um envolvimento quanto aos mesmos valores e sentidos dados aos enunciados, afastando do discurso pontos de vista pessoais do enunciador-autor.

No discurso científico, o posicionamento do enunciador-autor se revela desde o momento em que ele escolhe o seu referencial teórico até o da elaboração do texto. A construção discursiva nesse gênero textual se dá também a partir de outro discurso, a partir da voz do outro (polifonia). Ou seja, ocorre por meio de uma citação, literal ou indireta, que, ao corroborar o pensamento do enunciador-autor, legitima a sua opinião, em uma tentativa de persuadir o leitor. Sobre o emprego de tais citações, Ribeiro (2003) argumenta que seus objetivos têm "relação intrínseca com a questão da legitimidade, com a cientificidade do discurso, isto é, aquilo que é referido/definido por outros autores consagrados [...] é o que conferirá mais autoridade ao discurso do aluno-autor do texto científico." (RIBEIRO, 2003, online).

As análises presentes no universo teórico da Ciência da Informação e da Organização do Conhecimento que endossa essa visão encontram dialogicidade nos textos de Barros e Moraes $(2009,2010)$ e Barros $(2013,2014,2017)$, os quais buscam analisar o discurso por meio de textos científicos e evidenciam características similares as descritas neste artigo. Percebe-se que são instâncias semântico-discursivas do discurso científico para além das relações disciplinares; nesse sentido, esta pesquisa filia-se a esses estudos e os complementa.

Entende-se, assim, que a polifonia, conforme pesquisas anteriores, é utilizada para legitimar o discurso científico, tanto quando se demonstra concordância, como quando se apresenta uma opinião contrária ao do enunciador-autor. As citações enriquecem as discussões, fazendo parte das formações de sentido de um discurso até que esse discurso se constitua em um instrumento de persuasão e convença o leitor de que aqueles argumentos são plausíveis e legítimos, principalmente se ao autor da citação for conferido um status de destaque entre os acadêmicos de sua área. 


\section{O CONCEITO DE INTERVENCIONISMO EM ECONOMIA}

Não se pode tratar de intervencionismo em Economia sem levar em conta a sua relação semântica com outros termos, como "intervenção", por exemplo. Grau (1981, p. 63) diferencia intervencionismo e intervenção da seguinte forma: Intervencionismo: "[...] descrição do conjunto de ações [...] que o Estado, nos dias que correm, desenvolve no e sobre o processo econômico, objetivando a correção de distorções inevitáveis [...] visando à realização dos fins do Estado Social: justiça social e desenvolvimento." Intervenção: "[...] ação que o Estado empreende no e sobre um campo reservado à liberdade de iniciativa do setor privado - enfatizando que tal reserva não é peculiar do regime liberal, mas da essência do sistema capitalista".

Pelas definições de Grau (1981), é possível depreender que o primeiro termo se refere à ideologia, que é aplicada sobre a ação, e o segundo termo se refere à ação do Estado sobre determinado aspecto da sociedade. No entanto, esses termos aparecem na literatura especializada como variantes, o que pode ser constatado nos contextos em que há colocações como "intervenção do Estado" e "intervencionismo estatal".

Na macroestrutura do Novíssimo Dicionário de Economia (2016), principal obra terminológica da área, encontra-se apenas entrada para o termo "intervencionismo", porém este não apresenta definição; ele remete, por meio da expressão "Veja", ao termo "dirigismo", definido como "Tendência de o Estado manter uma intervenção reguladora permanente numa economia capitalista, em contraposição ao absenteísmo do Estado liberal" (SANDRONI, 2016, p. 552), e ao termo "gyosei shido", expressão japonesa traduzida literalmente por "indução administrativa" e definida como "[...] processo mediante o qual os organismos governamentais japoneses obtêm a adesão de indivíduos e/ou empresas a políticas e práticas consideradas desejáveis pelo governo." (SANDRONI, 2016, p. 849). Já o termo "intervenção" não possui entrada, mas aparece na microestrutura do dicionário, na definição (ou na explicação) de outros termos relacionados a intervencionismo.

Conquanto Grau (1981) apresente diferenças conceituais entre intervencionismo e intervenção, e Sandroni (2016) sugira apenas relações semânticas entre os termos, não explicitando se são equivalentes ou não, o corpus desta pesquisa possibilita constatar que o significado dos termos se confirma nos textos. Assim, assumir-se-á, nesta pesquisa, que "intervenção" e "intervencionismo" se tratam de variantes denominativas da área de Economia, uma vez que, nos discursos científicos dessa área, esses termos se equivalem.

O debate econômico contemporâneo tem resgatado polêmicas que não são exatamente originais na literatura. Entre os conceitos que se encontram no cerne da disputa teórico-ideológica, o intervencionismo parece galgar maior destaque. As atribuições inerentemente estatais passaram a ser questionadas a partir dos anos 1990, quando o chamado Consenso de Washington ${ }^{4}$ buscou atenuar a relevância do Estado na gestão de políticas públicas.

Independentemente da natureza da intervenção - se meio, como as políticas instrumentais de estabilização do ciclo, ou fim, como as institucionais -, o debate acerca da plausibilidade, ou, muitas vezes, da necessidade da intervenção do ente público no domínio econômico divide os analistas em grupos não exatamente antagônicos. O que se discute é a

\footnotetext{
4 "O Consenso de Washington tem origem em trabalho de John Williamson apresentado em 1989 (Williamson, 2004). É uma crítica ao pensamento e, principalmente, às experiências desenvolvimentistas na América Latina a partir de 1950. O Consenso de Washington apresenta diretrizes em relação às estratégias de desenvolvimento e políticas macroeconômicas. O enquadramento político-ideológico é, sem dúvida alguma, o neoliberalismo em ascensão nos anos 1980." (GONÇALVES, 2012, p. 654).
} 
maneira de se intervir, uma vez que, de acordo com Fonseca (2016), até mesmos governos de inspiração liberal não prescindem dos instrumentos estatais em suas administrações. 0 autor explica que o desenvolvimentismo, a social-democracia, o socialismo, o trabalhismo, a doutrina social cristã, o fascismo e o keynesianismo, apesar de se tratar de ideologias bastante díspares, todos eles recorrem, em algum grau, a medidas intervencionistas:

\begin{abstract}
Mas elas [ideologias] não podem ser apressadamente igualadas, pois diferem entre si não só na extensão da intervenção (desde a moderada cristã até a radical comunista), mas, principalmente, quanto ao objetivo e as razões da ação estatal [...]. Os intervencionismos também diferem entre si tanto na teoria (nas construções dos ideólogos e intelectuais) como na prática efetiva como políticas de Estado. (FONSECA, 2016, p. 4).
\end{abstract}

Percebe-se que esses termos formam um conjunto de conceitos que possui uma única estrutura e um núcleo temático, o intervencionismo; no entanto, esses conceitos se delineiam, e são nomeados, conforme os objetivos e as razões da ação estatal, demarcando as suas diferenças e ideologias. Desse modo, pode-se definir o intervencionismo, em termos gerais, como um regime econômico que se refere à ação do Estado sobre o domínio econômico em suas mais diferentes dimensões.

Dessa primeira definição decorre a necessidade de um melhor esclarecimento entre os conceitos de regime econômico e sistema econômico. O sistema econômico é uma forma de organização política, social e econômica de uma sociedade, em que estão incluídos a produção, a distribuição, o consumo de bens e serviços que a população utiliza visando ao seu bem-estar. Vasconcellos e Garcia (2014) classificam os sistemas econômicos em:

[1] sistema capitalista ou economia de mercado. É regido pelas forças de mercado, predominando a livre iniciativa e a propriedade privada dos fatores de produção; [2] sistema socialista ou economia centralizada ou, ainda, economia planificada. Nesse sistema as questões econômicas fundamentais são resolvidas por um órgão central de planejamento, predominando a propriedade pública dos fatores de produção, chamados nessas economias de meios de produção, englobando os bens de capital, terra, prédios, bancos, matérias-primas. (VASCONCELLOS; GARCIA, 2014, p. 4-5, grifo do autor).

Os autores argumentam que os países podem se organizar conforme esses sistemas ou, ainda, conforme um sistema de economia mista, que seria uma forma intermediária entre ambos, em que o mercado prevalece, mas o Estado atua complementarmente, financiando a produção de bens públicos, como nas áreas de educação, segurança, saúde, saneamento, justiça etc., ou incentivando investimentos do setor privado em setores como os de energia, transportes, comunicações.

Já o regime econômico pode ser definido como "um conjunto de princípios que orientam o exercício da atividade econômica, em seus vários níveis e setores" (GRAU, 1981, p. 60). Dessa forma, liberalismo e intervencionismo são considerados regimes econômicos, aplicados conforme a ideologia dos governantes em exercício.

Em sua obra Ideologia e aparelhos ideológicos do Estado, publicada originalmente em 1970, Althusser retoma a teoria marxista clássica do Estado, diferenciando os dois corpos do aparelho estatal: o corpo das instituições que representam o poder repressivo do Estado (o governo, a administração, o Exército, a polícia, os tribunais, as prisões etc.) e o corpo das instituições que representam o poder ideológico do Estado (AIE religioso, escolar, familiar, jurídico, político, econômico, sindical, cultural etc.). Segundo Althusser (1974, p. 56), esses corpos 
do aparelho estatal funcionam alternando repressão e ideologia, de modo que, em alguma medida, "a própria reprodução das relações de produção, 'escudados' no aparelho repressivo de Estado." Ademais, o aparelho instrumental do Estado funcionaria, segundo o autor, por meio da ideologia: "uma ideologia existe sempre num aparelho, e na sua prática ou suas práticas" (ALTHUSSER, 1974, p. 84).

Martins e Silva (2011) sugerem que a ideologia capitalista neoliberal prega que a intervenção do Estado é um mal para a economia e que a administração pública deve se afastar das questões econômicas e gerir somente a ordem política e social. Para os liberais, o mercado exerce um poder de autorregulação, de modo que a intervenção geraria apenas desemprego, distorções no sistema de preços e alocações ineficientes dos fatores produtivos.

Defensores do liberalismo econômico, Lisboa e Pessoa (2016) tecem críticas ao novodesenvolvimentismo, o qual defende a intervenção do Estado na indústria e no mercado de câmbio como mecanismos de fomento ao desenvolvimento econômico. Para os autores, o intervencionismo estatal só é recomendável no caso de externalidades - efeitos não controláveis que podem ser positivos ou negativos para a coletividade direta e indiretamente relacionadas aos setores nos quais se interveio:

Políticas de intervenção setorial são recomendáveis quando há evidências de externalidade, isto é, a atividade econômica apresenta impactos sobre os demais setores ou pessoas não capturados pelos preços de mercado. O exemplo clássico de externalidade negativa é a poluição e, mais geralmente, o impacto das atividades produtivas sobre o meio ambiente. (LISBOA; PESSOA, 2016, p. 181).

Conquanto minimizem a necessidade de atuação estatal, Lisboa e Pessoa (2016) reconhecem que o Estado pode intervir caso a empresa provoque danos ao meio ambiente ou consequências que prejudiquem terceiros; no entanto, se não houver evidências de externalidades importantes, não há por que o Estado intervir. Indo além, argumentam que a intervenção estatal colabora para a preservação de empresas ineficientes, impedindo que os fatores de produção sejam direcionados a empresas mais produtivas.

A respeito da dicotomia ideológica que se estabeleceu no referido debate, BresserPereira (1989, p. 118) aponta a circularidade nos discursos políticos em defesa de cada um dos extremos:

\footnotetext{
A esquerda apoia senão nacionalizações, pelo menos algum grau de intervenção estatal, enquanto a direita insiste num discurso neoliberal que abomina qualquer tipo de intervenção. Como o discurso da esquerda é uma mistura de ideologia e avaliação realista das limitações de mercado, o discurso da direita é o resultado de preconceitos ideológicos, de hipocrisia e de avaliação realista das distorções causadas pelo excesso de intervenção estatal. O caráter ideológico de ambos os discursos é completamente óbvio.
}

O autor procura, assim, qualificar a defesa do Estado que, a seu ver, deveria ser empunhada pelos setores progressistas. Em sua opinião, uma das vantagens da intervenção estatal é que, em economias subalternas, trata-se de condição necessária para que o país inicie um processo de industrialização. Segundo Bresser-Pereira (1989), as teorias sobre o crescimento equilibrado chamam a atenção para o papel fundamental do Estado na fase inicial de desenvolvimento econômico, favorecendo a classe empresarial por meio de incentivos fiscais e subsídios para as empresas, apoiando, assim, a acumulação privada de capital. 
Bresser-Pereira (1989, p. 121) defende que a intervenção estatal tem um caráter cíclico, buscando atenuar o desemprego dos fatores de produção - capital e trabalho - durante as inevitáveis crises recessivas por que periodicamente passam as economias capitalistas. Com tal fito, o Estado deveria assumir "um papel crescente na coordenação do sistema econômico, na microalocação de recursos, na macrodefinição do nível de poupança e investimento (ou do equilíbrio entre oferta e demanda agregada), e na micro-macrodeterminação da distribuição de renda entre as classes sociais e entre os setores da economia" até a estabilização da fase recessiva do ciclo econômico (BRESSER-PEREIRA, 1989, p. 121).

De modo sumarizado, observa-se que, para os defensores da intervenção, caberia ao Estado a tarefa de regular o mercado, ente que, por definição, necessita das balizas do governo a fim de atenuar os efeitos deletérios das recessões ou depressões econômicas. Do outro lado, os liberais, para os quais as crises econômicas resultam, justamente, da própria intervenção indevida do ente público. Assim, cabe ao Estado eximir-se de qualquer tipo de intervenção, permitindo que o mercado se autorregule e, assim, atue na alocação mais eficiente dos fatores produtivos de que dispõe uma sociedade.

\section{PROCEDIMENTOS PARA A ANÁLISE DO DISCURSO}

Conforme exposto na introdução, o corpus de estudo deste trabalho é composto por artigos publicados na Revista Análise Econômica no período 2015-2019. A metodologia utilizada é a Linguística de Corpus, que opera por meio "da coleta e da exploração de corpora, ou conjuntos de dados linguísticos textuais coletados criteriosamente, com o propósito de servirem para a pesquisa de uma língua ou variedade linguística" (BERBER SARDINHA, 2004, p. 3).

Para a compilação do corpus de estudo e seleção dos contextos, utilizou-se o software Sketch Engine. Trata-se de um gerenciador de corpus que permite ao pesquisador compilar grandes coleções de textos de acordo com o seu propósito. Uma de suas vantagens é a possibilidade de se fazer o upload dos textos em formato .pdf, não sendo necessário convertê-los para .txt para que ele os reconheça. Uma vez que os textos foram coletados, cada um deles recebeu um código correspondente à edição a qual pertence. Esse código permite ao analista identificar a referência do artigo durante a análise da colocação do termo em determinado contexto. ${ }^{5}$

Após essa codificação, fez-se o upload dos artigos para o software Sketch Engine, que destacou, por sua vez, as colocações das unidades terminológicas mapeadas ("intervenção" e "intervencionismo"), fornecendo, ao final, o número exato de ocorrências no corpus, conforme Figuras 1 e 2.

\footnotetext{
${ }^{5}$ Por exemplo, o código “RAE1608” corresponde ao oitavo artigo de 2016 publicado na revista.
} 
Figura 1 - Frequência do termo "intervenção"

\begin{tabular}{|c|c|c|c|c|}
\hline & File name & $\downarrow$ Frequency & Relative [\%] & \\
\hline 1 & RAE1811.doc & 28 & $2,466.2$ & $\ldots$ \\
\hline 2 & RAE1608.doc & 11 & $732.6 \rightleftharpoons$ & $\ldots$ \\
\hline 3 & RAE1802.docX & 10 & $1,239.7$ & $\ldots$ \\
\hline 4 & RAE1922.docX & 8 & $863.5=$ & $\ldots$ \\
\hline 5 & RAE1918.docX & 8 & $871.3=$ & $\ldots$ \\
\hline f & RAE1610.docX & 5 & $521.4=$ & $\ldots$ \\
\hline 7 & RAE1506.doc & 5 & $480.3-$ & $\ldots$ \\
\hline$B$ & RAE1921.docX & 4 & $377.6=$ & $\ldots$ \\
\hline 9 & RAE1718.docX & 3 & $281.6=$ & $\ldots$ \\
\hline 10 & RAE1711.docX & 3 & $412.9=$ & $\ldots$ \\
\hline 11 & RAE1917.docX & 2 & $298.9-$ & $\ldots$ \\
\hline 12 & RAE1806.doc $x$ & 2 & $249.2=$ & $\ldots$ \\
\hline 13 & RAE1716.docX & 2 & $250.9-$ & $\cdots$ \\
\hline 14 & RAE1611.docX & 2 & $555.8=$ & $\ldots$ \\
\hline 15 & RAE1507.doc & 2 & $242.9-$ & $\ldots$ \\
\hline 18 & RAE1920.docx & 1 & 99.9 . & $\ldots$ \\
\hline 17 & RAE1914.docX & 1 & 168 & $\ldots$ \\
\hline 18 & RAE1902.docX & 1 & 96.9 . & $\ldots$ \\
\hline 19 & RAE1827.docX & 1 & 98.8 . & $\ldots$ \\
\hline 20 & RAE 1822 doc $x$ & 1 & 100.9 & $\ldots$ \\
\hline 21 & RAE1818.doc & 1 & 110.8 & $\ldots$ \\
\hline 22 & RAE1803.docX & 1 & 75 . & $\ldots$ \\
\hline 23 & RAE1719.doc & 1 & $117.1=$ & $\ldots$ \\
\hline 24 & RAE1717.docX & 1 & $117.1 \ldots$ & $\ldots$ \\
\hline 25 & RAE1701.docX & 1 & 87.9 & $\ldots$ \\
\hline 26 & RAE1615.docX & 1 & 100.7 & $\ldots$ \\
\hline 27 & RAE1513.docX & 1 & 156.8 . & $\ldots$ \\
\hline 28 & RAE1510.doc & 1 & $217.3 \ldots$ & $\ldots$ \\
\hline 28 & RAE1508.doc & 1 & 88.9. & $\ldots$ \\
\hline
\end{tabular}

Fonte: Sketch Engine (2020). 
Figura 2 - Frequência do termo "intervencionismo"

\begin{tabular}{|c|c|c|c|c|}
\hline & File name & $\downarrow$ Frequency & Relative [\%] & \\
\hline 1 & RAE1922.doc $X$ & 20 & 8,715 & $\cdots$ \\
\hline 2 & RAE1717.doc $X$ & 3 & $1,418.2=$ & $\ldots$ \\
\hline 3 & RAE1608.doc & 3 & $806.6-$ & $\ldots$ \\
\hline 4 & RAE1916.docX & 1 & 364.7 & $\ldots$ \\
\hline
\end{tabular}

Fonte: Sketch Engine (2020).

Após a seleção dos artigos que continham as ocorrências, analisaram-se as colocações em seus contextos por meio da leitura humana, uma vez que "os programas de análise de corpora partem da identificação de formas linguísticas e não de seus significados" (BERBER SARDINHA, 2010, p. 171).

Definido o corpus, que é onde se materializa o discurso, destacam-se os traços linguísticos e discursivos a serem levados em consideração no estudo. Cada analista mobiliza conceitos diversos e particulares de seu objeto, dependendo do domínio científico ao qual se vincula a sua pesquisa.

Assim, com base nos procedimentos apresentados por Pêcheux e Fuchs (1975), Orlandi (2009) e Barros (2017), este último, utilizando uma série de tipologias textuais, como editoriais científicos (EVANGELISTA; BARROS; MORAES, 2018), artigos científicos (BARROS, 2017), manuais técnicos (BARROS, 2015), políticas de indexação (GARCIA et al., 2019), normas de descrição arquivística (MARTINS; BARROS.; MORAES, 2019), códigos de ética (SILVA; BARROS; MORAES, 2018) teses e dissertações (DANTAS et al., 2018; MARTINS et al., 2019), encontrando lastro enquanto recorde metodológico, propõe-se, no Quadro 1, um percurso de como proceder em uma análise de discurso.

Para um melhor entendimento do Quadro 1, traçou-se o seguinte percurso de ações com base em Orlandi (2009):

Enunciação/Superfície linguística: escolher o corpus de estudo; formular a questão que irá desencadear a análise; "Como" este texto significa?; mobilizar os conceitos pertinentes à questão formulada.

Paráfrase/Esquecimento 2 (consciente)/Objeto discursivo: observar o modo de construção, a estruturação, o modo de circulação e os diferentes gestos de leitura que constituem os sentidos do texto (gestos de interpretação que produzem efeitos).

Discurso/Esquecimento 1 (inconsciente)/Processo discursivo: comparar os sentidos do discurso em análise com o que é dito em outros discursos, com o que não é dito, e com o que poderia ser dito e não foi; verificar os dizeres, seus efeitos de sentido e sua exterioridade (condições em que os dizeres são produzidos); desenvolver a análise a partir dos vestígios que os dizeres vão deixando no texto; delinear as formações discursivas (ir além do que o discurso diz, do que fica na superfície das evidências); comparar as formações discursivas com outras que coexistam no mesmo momento histórico; verificar relações antagônicas; relacionar o discurso com a ideologia (compreender como se constituem os sentidos do dizer, o que a mobilização de certas palavras pode mostrar além das aparências); verificar as palavras que refletem sentidos de discursos já realizados, imaginados ou possíveis; relacionar o discurso com outros discursos; verificar paráfrases (mobilizar outras palavras, produzindo outros efeitos de sentido), metáforas, si- 
nonímias; observar os gestos de interpretação, ou seja, o modo de constituição dos sujeitos e da produção dos sentidos (filiações de sentidos que remetem a memórias e a circunstâncias que mostram que os sentidos não estão só nas palavras, nos textos, mas na relação com a exterioridade, nas condições em que eles são produzidos e que não dependem só das intenções dos sujeitos).

Quadro 1 - Proposta de percurso para uma análise de discurso

\begin{tabular}{|c|c|c|}
\hline Enunciação/Superfície linguística & $\begin{array}{c}\text { Paráfrase/Esquecimento } 2 \\
\text { (consciente) }\end{array}$ & $\begin{array}{c}\text { Discurso/Esquecimento } 1 \\
\text { (inconsciente) }\end{array}$ \\
\hline \multirow{2}{*}{$\begin{array}{l}\text { "[...] entendida no sentido de } \\
\text { sequência oral ou escrita de di- } \\
\text { mensão variável, em geral superi- } \\
\text { or à frase. Trata-se aí de um "dis- } \\
\text { curso" concreto, isto é, do objeto } \\
\text { empírico afetado pelos esqueci- } \\
\text { mentos } 1 \text { e } 2 \text {, na medida mesmo } \\
\text { em que o lugar de sua realização, } \\
\text { sob a forma, coerente e subjeti- } \\
\text { vamente vivida como necessária, } \\
\text { de uma dupla ilusão." (PÊCHEUX; } \\
\text { FUCHS, 1975, p. 180). }\end{array}$} & $\begin{array}{l}\text { Esquecimento no 2: enunciação (ob- } \\
\text { servar o como se diz ou o como não } \\
\text { se diz, o quem diz (o domínio), em } \\
\text { que circunstâncias se diz (posição } \\
\text { dos sujeitos na história), pois ao } \\
\text { longo do dizer, formam-se famílias } \\
\text { parafrásticas que indicam que o dizer } \\
\text { poderia ser x e não y. }\end{array}$ & $\begin{array}{l}\text { Verificar o processo de materia- } \\
\text { lidade linguística: esquecimento } \\
\text { 1: ideológico, inconsciente (re- } \\
\text { sulta no modo pelo qual se é } \\
\text { afetado pela ideologia). }\end{array}$ \\
\hline & $\begin{array}{l}\text { Objeto Discursivo... } \\
\text { “[...] entendido como o resultado da } \\
\text { transformação da superfície linguísti- } \\
\text { ca de um discurso concreto, em um } \\
\text { objeto teórico, isto é, em um objeto } \\
\text { lingüisticamente de-superficializado, } \\
\text { produzido por uma análise lingüística } \\
\text { que visa a anular a ilusão no 2." } \\
\text { (PÊCHEUX; FUCHS, 1975, p. 180). }\end{array}$ & $\begin{array}{l}\text { Processo Discursivo } \\
\text { "[...] entendido como o resulta- } \\
\text { do da relação regulada de obje- } \\
\text { tos discursivos correspondentes } \\
\text { a superfícies lingüísticas que } \\
\text { derivam, elas mesmas, de con- } \\
\text { dições de produção estáveis e } \\
\text { homogêneas. Este acesso ao } \\
\text { processo discursivo é obtido por } \\
\text { uma de-sintagmatização que } \\
\text { incide na zona de ilusão- } \\
\text { esquecimento no 1." (PÊCHEUX; } \\
\text { FUCHS, 1975, p. 181). }\end{array}$ \\
\hline
\end{tabular}

Fonte: Elaboração própria a partir de Pêcheux e Fuchs (1975, p. 180-181), Orlandi (2009, p. 64-72) e Barros (2017, p. 103).

Destaca-se que a leitura de um discurso não é um processo passivo; pelo contrário, trata-se de fenômeno ativo, no sentido de que há um engajamento nas tentativas de se extrair sentidos do discurso. Cada análise é particular e cada analista constrói o seu dispositivo analítico, mobilizando os seus conceitos conforme a questão que deseja responder: "o que define a forma do dispositivo analítico é a questão posta pelo analista, a natureza do material e a finalidade da análise." (ORLANDI, 2009, p. 27). Da construção do dispositivo analítico vai depender o alcance das conclusões a que se chegar.

\section{ANÁLISE DOS RESULTADOS}

Com o auxílio do gerenciador de corpus Sketch Engine, rastrearam-se, em um universo de 131 artigos da Revista Análise Econômica entre 2015 e 2019, os artigos que continham ocorrências dos termos "intervencionismo" e "intervenção". Desse rastreamento, 30 artigos apresentaram ocorrências para esses termos. Identificaram-se 109 ocorrências do termo "intervenção" e 27 ocorrências do termo "intervencionismo". Com vistas a otimizar a funcionalidade da análise, utilizou-se uma proxy de três artigos, tendo como parâmetro um mínimo de oito ocorrências do mesmo termo ou dos dois termos, em cada um dos artigos.

Assim, com base no primeiro quadro, elaborou-se o Quadro 2 com vistas a analisar os enunciados selecionados no software a partir dos artigos recortados. Esses enunciados fo- 
ram escolhidos justamente pela sua importância em relação a uma série de vínculos enunciativos aos termos "intervenção" e "intervencionismo". O levantamento das colocações possibilita a verificação de como os autores conceituam intervencionismo, e, por fim, se o mesmo é expresso por uma perspectiva positiva ou negativa.

Quadro 2 - Análise do discurso dos artigos da Revista Análise Econômica do período 2015-2019 Temática "intervencionismo"

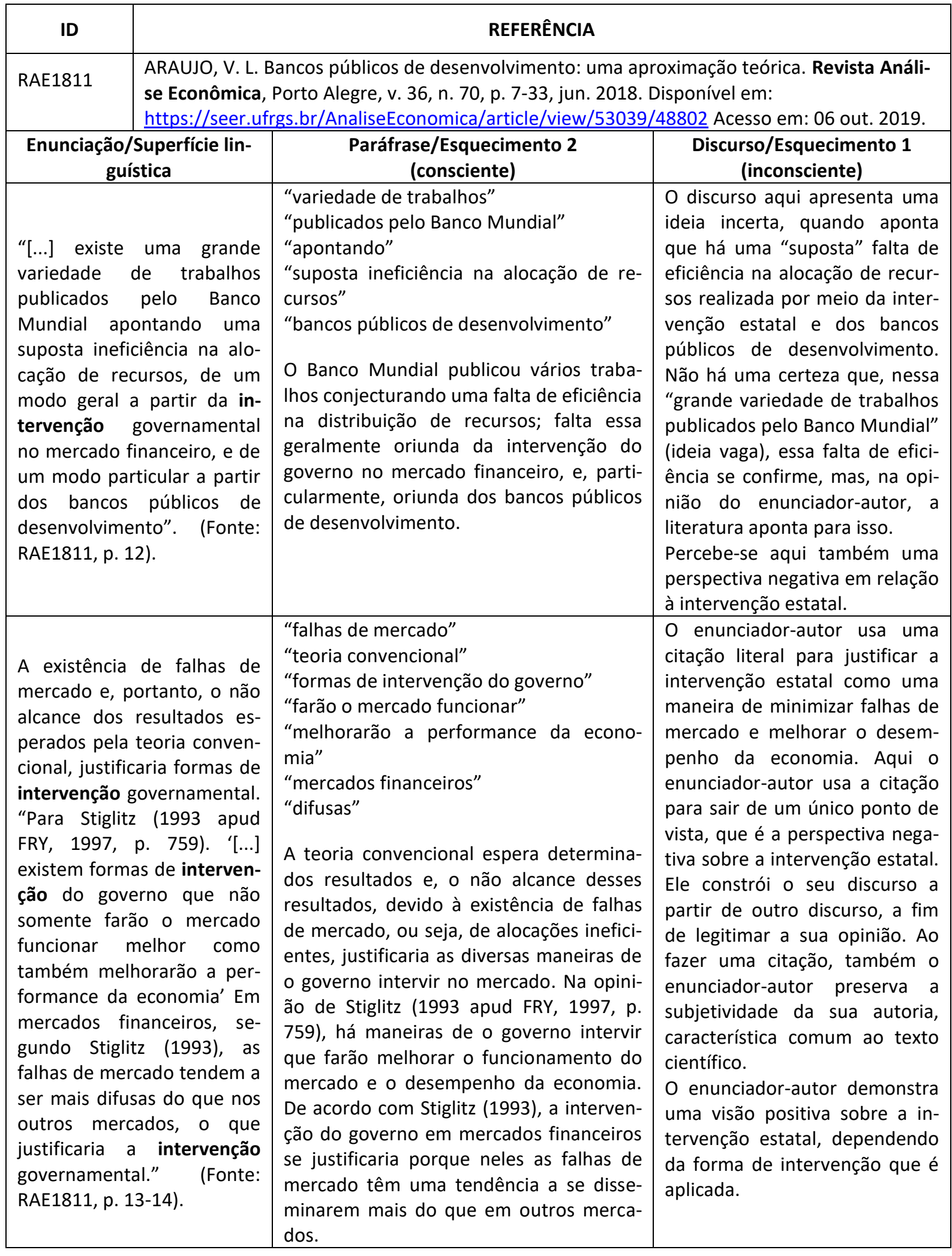




\begin{tabular}{|c|c|c|}
\hline \multicolumn{3}{|c|}{ REFERÊNCIA } \\
\hline \multicolumn{3}{|c|}{$\begin{array}{l}\text { MOREIRA, A. G.; AREND, M. Que estratégia de desenvolvimento seguir? O debate desenvol- } \\
\text { vimentista brasileiro no século XXI. Revista Análise Econômica, Porto Alegre, v. 34, n. 65, p. } \\
\text { 205-239, mar. 2016. Disponível em: } \\
\text { https://seer.ufrgs.br/AnaliseEconomica/article/view/47299/36643 Acesso em: } 20 \text { out. } 2019 .\end{array}$} \\
\hline $\begin{array}{c}\text { Enunciação/Superfície lin- } \\
\text { guística }\end{array}$ & $\begin{array}{c}\text { Paráfrase/Esquecimento } 2 \\
\text { (consciente) }\end{array}$ & $\begin{array}{c}\text { Discurso/Esquecimento } 1 \\
\text { (inconsciente) }\end{array}$ \\
\hline $\begin{array}{l}\text { "Em relação ao Brasil, a } \\
\text { presença mais destacada da } \\
\text { intervenção estatal na di- } \\
\text { nâmica econômica nos anos } \\
2000 \text { contribuiu para uma } \\
\text { taxa média de crescimento } \\
\text { econômico mais elevada e } \\
\text { para a melhora nos indica- } \\
\text { dores de distribuição de } \\
\text { renda, retomando, por con- } \\
\text { seguinte, o debate sobre } \\
\text { estratégias nacionais de } \\
\text { desenvolvimento." } \\
\text { (Fonte: RAE1608, p. 206). }\end{array}$ & $\begin{array}{l}\text { "presença mais destacada" } \\
\text { "dinâmica econômica nos anos 2000" } \\
\text { "contribuiu" } \\
\text { "taxa média de crescimento econômico } \\
\text { mais elevada" } \\
\text { "melhora nos indicadores de distribuição } \\
\text { de renda" } \\
\text { "retomando" } \\
\text { "debate sobre estratégias nacionais de } \\
\text { desenvolvimento" } \\
\text { A intervenção do Estado foi mais atuante } \\
\text { no desempenho econômico brasileiro nos } \\
\text { anos } 2000, \text { quando, por sua causa, o Bra- } \\
\text { sil obteve uma taxa média de crescimento } \\
\text { econômico mais elevada e um aumento } \\
\text { nos números de distribuição de renda, } \\
\text { trazendo à luz novamente discussões } \\
\text { sobre planos de desenvolvimento para o } \\
\text { país. }\end{array}$ & $\begin{array}{l}\text { Em um artigo de 2016, o enun- } \\
\text { ciador-autor remete o leitor ao } \\
\text { contexto histórico dos anos } \\
2000 \text {, mostrando os avanços } \\
\text { obtidos pela intervenção estatal } \\
\text { e mencionando que os indica- } \\
\text { dores positivos da época foram } \\
\text { responsáveis por trazerem de } \\
\text { volta o debate sobre planos de } \\
\text { crescimento para o país. Ele } \\
\text { relaciona a memória dos anos } \\
2000 \text { à situação atual (no caso, } \\
2016 \text { ). } \\
\text { A visão do enunciador-autor } \\
\text { sobre a intervenção estatal aqui } \\
\text { é positiva. }\end{array}$ \\
\hline $\begin{array}{l}\text { "A questão da intervenção } \\
\text { estatal na corrente da Casa } \\
\text { das Garças remete a princí- } \\
\text { pios relativos ao approach } \\
\text { neoclássico e, na maioria } \\
\text { das vezes, é condenável. } \\
\text { Bacha (2013) propõe que o } \\
\text { Estado seja um agente con- } \\
\text { fiável, que antecipe suas } \\
\text { decisões para o mercado } \\
\text { poder agir com tranquilida- } \\
\text { de, e que consiga estabele- } \\
\text { cer um consenso social e } \\
\text { político em torno do projeto } \\
\text { de integração." (Fonte: } \\
\text { RAE1608, p. 224). }\end{array}$ & $\begin{array}{l}\text { "corrente da Casa das Garças" } \\
\text { "approach neoclássico" } \\
\text { "agente confiável" } \\
\text { "consenso social e político" } \\
\text { "projeto de integração" } \\
\text { O grupo de estudos da Casa das Garças } \\
\text { liga a intervenção do Estado a conceitos } \\
\text { relacionados à abordagem neoclássica e } \\
\text { isso, na maioria das vezes, é reprovável. } \\
\text { Na proposta de Bacha (2003), é preciso } \\
\text { que o Estado seja digno de confiança, } \\
\text { tomando decisões antecipadamente - } \\
\text { para que o mercado possa operar de } \\
\text { maneira tranquila -, e criando um acordo } \\
\text { social e político que viabilize o plano de } \\
\text { integração. }\end{array}$ & $\begin{array}{l}\text { A Casa das Garças é um Institu- } \\
\text { to de Estudos de Política Eco- } \\
\text { nômica, que se define "como } \\
\text { uma associação civil de direito } \\
\text { privado sem fins econômicos, à } \\
\text { qual é vedado participar de } \\
\text { quaisquer atividades de caráter } \\
\text { político-partidário ou religioso. } \\
\text { Seu objeto é promover estudos, } \\
\text { pesquisas, seminários, debates, } \\
\text { cursos e publicações, visando a } \\
\text { discutir a realidade sócio- } \\
\text { econômica do País." (IEPE/CdG, } \\
\text { 2020, on-line). O enunciador- } \\
\text { autor critica o pensamento da } \\
\text { corrente da Casa das Garças } \\
\text { sobre o intervencionismo. Ele } \\
\text { reprova a ligação que esse gru- } \\
\text { po de estudos faz entre inter- } \\
\text { vencionismo e abordagem neo- } \\
\text { clássica da Economia, a qual } \\
\text { defende a formação dos preços, } \\
\text { a produção e a distribuição da } \\
\text { renda através da oferta e de- } \\
\text { manda dos mercados. Por ter } \\
\text { um viés ideológico liberal, a } \\
\text { corrente Casa das Garças pode } \\
\text { ter dado um valor à intervenção } \\
\text { estatal diferente do esperado }\end{array}$ \\
\hline
\end{tabular}




\begin{tabular}{|c|c|c|}
\hline & & $\begin{array}{l}\text { pelo enunciador-autor, por isso } \\
\text { ele considera a abordagem } \\
\text { condenável. Logo em seguida, } \\
\text { cita indiretamente de Edmar } \\
\text { Bacha, que propõe que o Estado } \\
\text { seja um agente confiável por } \\
\text { antecipar suas decisões para o } \\
\text { mercado. Um tipo de interven- } \\
\text { cionismo que privilegie o mer- } \\
\text { cado com informações anteci- } \\
\text { padas para que ele possa agir } \\
\text { com mais segurança. } \\
\text { Bacha é um autor que tem sua } \\
\text { formação ideológica diretamen- } \\
\text { te atrelada a seus laços institu- } \\
\text { cionais, no caso, a Casa das } \\
\text { Garças, instituição assumida- } \\
\text { mente de viés liberal. }\end{array}$ \\
\hline \multicolumn{3}{|c|}{ REFERÊNCIA } \\
\hline \multicolumn{3}{|c|}{$\begin{array}{l}\text { VARASCHIN, J. A. A. Os sentidos da ação estatal nos anos 1930: centralização política e inter- } \\
\text { vencionismo na constituição de 1934. Revista Análise Econômica, Porto Alegre, v. 37, n. 74, } \\
\text { p. 141-164, set. 2019. Disponível em: } \\
\text { https://seer.ufrgs.br/AnaliseEconomica/article/view/77409/54387 Acesso em: } 12 \text { out. } 2019 .\end{array}$} \\
\hline $\begin{array}{c}\text { Enunciação/Superfície lin- } \\
\text { guística }\end{array}$ & $\begin{array}{c}\text { Paráfrase/Esquecimento } 2 \\
\text { (consciente) }\end{array}$ & $\begin{array}{c}\text { Discurso/Esquecimento } 1 \\
\text { (inconsciente) }\end{array}$ \\
\hline $\begin{array}{l}\text { "Nesse contexto, vê-se o } \\
\text { início da formação de um } \\
\text { sujeito nacional calcado na } \\
\text { ideia de "interesse nacio- } \\
\text { nal", a defesa do interven- } \\
\text { cionismo estatal, criando os } \\
\text { primeiros instrumentos } \\
\text { jurídicos para tanto, uma } \\
\text { maior centralização política } \\
\text { por parte do governo fede- } \\
\text { ral e um nascente tom naci- } \\
\text { onalista, como veremos } \\
\text { adiante." (Fonte: RAE1922, } \\
\text { p. 157). }\end{array}$ & $\begin{array}{l}\text { "formação" } \\
\text { "sujeito nacional" } \\
\text { "ideia de "interesse nacional" } \\
\text { "defesa do intervencionismo estatal" } \\
\text { "primeiros instrumentos jurídicos" } \\
\text { "maior centralização política" } \\
\text { "nascente tom nacionalista" } \\
\text { A promulgação da Constituição de } 1934 \\
\text { deu início à concepção de um sujeito } \\
\text { nacional, que defendia, como principal } \\
\text { "interesse do país", o intervencionismo } \\
\text { do Estado. Para tanto, foram criados os } \\
\text { primeiros acordos, contratos, convênios e } \\
\text { protocolos e uma política mais centraliza- } \\
\text { da por parte do governo federal. Também } \\
\text { começou a despontar no horizonte a } \\
\text { formação de um caráter nacionalista, } \\
\text { como será visto mais adiante. }\end{array}$ & $\begin{array}{l}\text { O enunciador-autor remete o } \\
\text { leitor ao contexto histórico } \\
\text { nascente da Constituição de } \\
\text { 1934. É possível perceber como } \\
\text { o intervencionismo estatal, } \\
\text { nessa época, estava ligado ao } \\
\text { nacionalismo, e que os instru- } \\
\text { mentos jurídicos criados nessa } \\
\text { época eram mais voltados ao } \\
\text { intervencionismo do que nas } \\
\text { épocas seguintes. }\end{array}$ \\
\hline $\begin{array}{l}\text { “Conquanto a República } \\
\text { Velha não estivesse diante } \\
\text { de um Estado absenteísta - } \\
\text { as políticas do café vinham } \\
\text { de longa data -, a partir de } \\
1930 \text { o intervencionismo } \\
\text { não só passou a abranger os } \\
\text { diversos segmentos da eco- } \\
\text { nomia e da sociedade e se } \\
\text { expandiu verticalmente em } \\
\text { cada setor, incorporando-se } \\
\text { ao modus operandi do go- }\end{array}$ & $\begin{array}{l}\text { "República Velha" } \\
\text { "Estado absenteísta" } \\
\text { "políticas do café" } \\
\text { "diversos segmentos da economia e da } \\
\text { sociedade" } \\
\text { "expandiu verticalmente" } \\
\text { "modus operandi do governo" } \\
\text { "transformou-se em ideologia" } \\
\text { Embora no período de 1889-1930 não } \\
\text { houvesse absenteísmo estatal - as políti- } \\
\text { cas do café perduraram por longa data -, }\end{array}$ & $\begin{array}{l}\text { O enunciador-autor deixa mar- } \\
\text { cado, por meio de citação indi- } \\
\text { reta, que o intervencionismo, } \\
\text { nos anos 30, estava tão incor- } \\
\text { porado às ações governamen- } \\
\text { tais que se tornou uma ideolo- } \\
\text { gia. }\end{array}$ \\
\hline
\end{tabular}




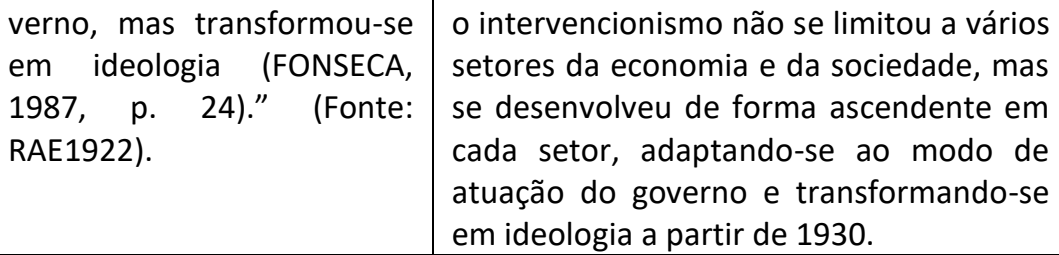

Fonte: Elaboração própria.

Nota: ID = identificação da referência.

A leitura dos excertos revelou uma tendência dos enunciadores-autores dos textos científicos sobre os seus posicionamentos em relação ao seu viés ideológico: se liberal ou intervencionista e, evidentemente, a tendência inconsciente de seu apagamento. Os enunciados permitiram verificar como os autores conceituam intervencionismo, e se esse conceito é expresso por uma perspectiva positiva ou negativa para os economistas, com exceção dos enunciados que apresentaram apenas o contexto histórico, o que serviu somente para ilustrar o panorama de um período determinado, sem conter juízos de valor.

Assim, para clarear essa questão sobre o viés ideológico contido nos textos, foi necessária a leitura completa dos três artigos selecionados. No primeiro (RAE1811), constatouse que o enunciador-autor defende a atuação dos bancos públicos de desenvolvimento no mercado financeiro. Essa medida seria uma forma de intervenção estatal e seria positiva na medida em que esses bancos ocupam o mesmo nível hierárquico dos bancos privados, sendo principais financiadores do desenvolvimento econômico brasileiro; resumida de modo sistemática, infere-se que os críticos da intervenção estatal no mercado financeiro rejeitam a atuação dos bancos públicos.

O enunciador-autor mostra-se a favor dessa atuação dos bancos públicos por um viés pós-keynesiano, pelo qual se defende a intervenção no mercado monetário a fim de se mitigar contrações ou expansões de liquidez consideradas exageradas ou indevidas. Faz-se claro, portanto, o viés intervencionista desse enunciador-autor por todas as suas tentativas de convencer o leitor de que a política monetária pós-keynesiana seria melhor do que a visão convencional, de liberalização financeira, que defende soluções privadas para o financiamento das atividades produtivas.

No segundo artigo (RAE1922), o enunciador-autor propõe um estudo de algumas das principais correntes de pensamento econômico no Brasil contemporâneo - o novodesenvolvimentismo, o social-desenvolvimentismo e o programa (neo)liberal da Casa das Garças. As três correntes admitem, em graus variados, a intervenção estatal, divergindo, porém, no modo como o Estado deve se posicionar frente a ela. Pela análise dos enunciados, o enunciador-autor admite que a intervenção estatal é imprescindível para o desenvolvimento de um país, sendo que, no caso brasileiro, ela havia sido aplicada de maneira ideológica até os anos 1980. Para o enunciador-autor, o intervencionismo é condição necessária ao desenvolvimento, desde que respeitando leis universais das economias de mercado.

No terceiro artigo (RAE1922), o enunciador-autor analisa as ações da intervenção estatal nos anos 1930, quando houve uma ruptura quanto ao viés liberal do governo, inaugurando uma nova fase no capitalismo brasileiro. Segundo a análise de contextos históricos realizados pelo autor, a Constituição de 1934 possibilitou a criação de instrumentos jurídicos que ensejavam a intervenção do Estado no domínio econômico. Ao analisar os discursos no debate para a elaboração da Constituição de 1934, o autor sugere que se tratou de um marco para a implementação de uma política antiliberal que surgia no país; tratava-se da formação do estado desenvolvimentista brasileiro (BIELSCHOWSKY, 2004). 


\section{CONSIDERAÇÕES FINAIS}

A finalidade deste artigo foi identificar, no discurso científico de alguns artigos publicados na Revista Análise Econômica, no período 2015-2019, as colocações dos termos "intervenção" e "intervencionismo" em seus contextos e, desse modo, rastrear seus vieses ideológicos - se intervencionista ou liberal - por meio da Linguística de Corpus visando à análise do discurso. A pesquisa se limitou ao domínio de Economia. Pelos resultados obtidos, é possível concluir que o termo "intervenção" é o termo preferido pelos autores da revista em seus discursos científicos nesse período, diferentemente do que está estabelecido no Novíssimo Dicionário de Economia (2016), que traz como termo preferido "intervencionismo". Faulstich (2006, p. 28) explica que, quando um termo é preferido em um discurso científico, a ele é atribuído "o maior peso de valor ideológico", "podendo ser registrado nos dicionários terminológicos." No entanto, não cabe a esta pesquisa fazer uma análise crítica da referida obra terminológica, pois seria preciso ter acesso ao percurso metodológico realizado pelo organizador da obra para saber o que lhe garantiu registrar "intervencionismo" como termo preferido. Por meio do corpus desta pesquisa foi possível constatar que o significado dos termos se confirma em seus contextos de ocorrência, os quais demonstraram que "intervenção" e "intervencionismo" se comportam como variantes denominativas da área de Economia, uma vez que, nos discursos científicos da área, esses termos se equivalem.

A intenção deste artigo foi compreender o viés ideológico presente em artigos científicos da revista no período 2015-2019, porém essa tarefa nem sempre é fácil, devido a toda uma padronização que este gênero textual precisa seguir para conferir-lhe um caráter de cientificidade, conforme já destacado por Barros (2015). Nesse gênero textual, a ideologia se faz presente de uma forma muito sutil, às vezes, sendo percebida quando o autor constrói o seu discurso a partir de outro discurso, ou seja, a partir das formações que se filia, quer seja por um comentário em nota de rodapé, quer seja pelos autores que o enunciador-autor utiliza, nas citações diretas ou indiretas, para legitimar sua argumentação, construindo assim o seu discurso a partir de outros discursos. Nesse caso, o conhecimento extralinguístico do analista é essencial para reconhecer a importância do autor citado e qual o seu posicionamento ideológico em outros textos de sua autoria já publicados.

O levantamento das colocações dos termos "intervenção" e "intervencionismo" em seus contextos por meio da Linguística de Corpus ajudou bastante na análise do discurso. A partir dessa metodologia, foi possível verificar o valor dado a cada termo em determinada situação discursiva, porém, ela não substituiu a leitura integral dos textos, o que possibilitou ao analista uma visão mais ampliada das intenções discursivas do enunciador-autor, sinalizando que seu uso deve ser considerado para outras tipologias textuais e formulações discursivas. Só a partir da leitura integral é que foi possível depreender a perspectiva dos autores - se positiva ou negativa - em relação ao conceito, que se delineou conforme os objetivos e as razões da ação estatal, demarcando assim as suas diferenças e ideologias.

Destaca-se que, no âmbito da Ciência da Informação, o levantamento de termos em seus contextos discursivos tem se mostrado imprescindível para a validação de conceitos em determinados domínios, visando ao aperfeiçoamento de Sistemas de Organização do Conhecimento, tais como vocabulários controlados e glossários. Para tanto, a Linguística de Corpus, como abordagem de corpus, e a Análise do Discurso, como metodologia de análise de textos científicos, têm contribuído para a Organização do Conhecimento, uma vez que, para que se elaborem sistemas de acesso à informação, além de tecnologia, é preciso en- 
tender a informação e seus múltiplos sentidos. Nesse contexto, a Análise do Discurso, como teoria dos sentidos, pode auxiliar o pesquisador a conhecer o domínio que determinado conceito representa e, assim, a elaborar definições ou notas explicativas para conceitos e seus variados registros dentro de um universo de conhecimento.

Nesse contexto, com relação à dicotomia ideológica intervencionismo/liberalismo presente nos artigos publicados no período $2015-2019,{ }^{6}$ o que se constatou no que foi dito foi um viés pró-intervencionismo nos três artigos analisados, onde todos eles afirmam que a intervenção estatal é uma ação positiva, essencial ao desenvolvimento do país, e que isso pode ser evidenciado por meio da história.

\section{REFERÊNCIAS}

ALTHUSSER, L. Ideologia e aparelhos ideológicos do Estado. Trad. Joaquim José de Moura Ramos. Portugal: Presença; Brasil: Martins Fontes, 1974.

ARAUJO, V. L. Bancos públicos de desenvolvimento: uma aproximação teórica. Revista Análise Econômica, Porto Alegre, v. 36, n. 70, p. 7-33, jun. 2018. Disponível em:

https://seer.ufrgs.br/AnaliseEconomica/article/view/53039/48802 Acesso em: 06 out. 2019.

BARROS, T. H. B. Discurso, documento e arquivística: trajetória de uma área. Pesquisa Brasileira em Ciência da Informação e Biblioteconomia, João Pessoa, v. 12, n. 2, p. 97-110, 2017.

Os Arquivos, a Arquivística e o Discurso: alguns marcos históricos e conceituais. Informação Arquivística, v. 2, n. 1, p. 135-157, 2013.

Por uma Arqueologia da Arquivística: elementos históricos de sua constituição. Informação Arquivística, v. 3, n.2, p. 6-28, 2014.

. Uma trajetória da Arquivística a partir da Análise do Discurso: inflexões históricoconceituais. São Paulo: Editora UNESP, 2015. v. 1. 267 p.

BARROS, T. H. B.; MORAES, J. B. E. A construção discursiva em Arquivística: aspectos culturais e ideológicos. In: ROMERO, N. L. (Org.). Nuevas Perspectivas para la Difusión y Organización del Conocimiento. Valência: Ed. Universidad Politécnica de Valencia, 2009. v. 1. p. 499512.

From archives to archival science: elements for a discursive construction. In: GNOLI, C. (Ed.). (Org.). Paradigms and conceptual systems in Knowledge Organization. Würzburg: ERGON VERLAG, 2010. p. 388-404.

BERBER SARDINHA, T. B. As metáforas do presidente Lula na perspectiva da linguística de corpus: o caso do desenvolvimento. Delta, v. 26, n. 1, p. 163-190, 2010.

\footnotetext{
${ }^{6}$ Para pesquisas futuras, sugere-se o levantamento de termos em artigos publicados em períodos anteriores, a fim de se constatar o viés ideológico predominante no discurso científico, e se esse viés está alinhado com a ideologia dos que estavam no governo no período analisado. É possível existir um discurso que varie diacronicamente, mas também um discurso que varie conforme a revista analisada.
} 
. Linguística de corpus. Barueri, SP: Manole, 2004.

BIELSCHOWSKY, R. Pensamento Econômico Brasileiro, 1930-1964: o ciclo ideológico do desenvolvimento. Rio de Janeiro: Contraponto, 2004.

BRESSER-PEREIRA, L. C. O caráter cíclico da intervenção estatal. Revista de Economia Política, v. 9, n. 3, p. 115-130, jul.-set. 1989.

CAVALCANTE FILHO, U. Como funciona o discurso do gênero divulgação científica? Cadernos do CNLF, v. 14, n. 2, tomo 1, 2010. Disponível em:

http://www.filologia.org.br/xiv_cnlf/tomo_1/757-770.pdf. Acesso em: 25 fev. 2020.

CHOMSKY, N. Form and meaning in natural languages. In: . Language and mind. 3. ed. Cambridge: Cambridge University Press, 2006. p. 88-101.

DANTAS, C. F. N. et al. A produção científica da UFPA sobre conhecimentos tradicionais. Incid: Revista de Documentação e Ciência da Informação, v. 9, n. 2, p. 48-70, 2018.

DEMO, P. Demarcação científica. In: . Metodologia científica em ciências sociais. 3 ed. São Paulo: Atlas, 1995. p. 16-40.

EVANGELISTA, I. V.; BARROS, T. H. B.; MORAES, J. B. E. Uma análise do discurso da dimensão cultural da International Society for Knowledge Organization. Informação \& Sociedade - Estudos, v. 28, n. 2, p. 37-47, 2018.

FAULSTICH, E. A socioterminologia na comunicação científica e técnica. Ciência e Cultura, São Paulo, v. 58, n. 2, p. 27-31, June 2006. Disponível em:

http://cienciaecultura.bvs.br/scielo.php?script=sci_arttext\&pid=S0009-

67252006000200012\&lng=en\&nrm=iso. Acesso em: 10 mar. 2020.

FONSECA, P. C. D. Prejuízo conceitual: intervencionismo não é sinônimo de desenvolvimentismo. Folha de São Paulo, 6 mar. 2016, p. 4-5. Disponível em:

http://professor.ufrgs.br/pedrofonseca/publications/prejuzo-conceitual-intervencionismonão-é-sinônimo-de-desenvolvimentismo-0. Acesso em 14 mar. 2020.

GARCIA, V. C. et al. Política de indexação e seus sentidos: um estudo a partir da Análise do Discurso. Informação \& Informação (Online), v. 24, n. 1, p. 169, 2019.

GONÇALVES, R. Novo desenvolvimentismo e liberalismo enraizado. Serviço Social \& Sociedade, São Paulo, n. 112, p. 637-671, dez. 2012. Disponível em:

https://www.scielo.br/pdf/sssoc/n112/03.pdf. Acesso em: 07 jul. 2020.

GRAU, E. R. Elementos de Direito Econômico. São Paulo: Revista dos Tribunais, 1981. INSTITUTO DE ESTUDOS DE POLÍTICA ECONÔMICA/CASA DAS GARÇAS (IEPE/CdG). Quem somos? Disponível em: http://iepecdg.com.br/quem-somos. Acesso em: 16 mar. 2020.

LEFFA, V. J. Interpretar não é compreender: um estudo preliminar sobre a interpretação de texto. In: LEFFA, V. J.; ERNST, A. (Org.). Linguagens: metodologia de ensino e pesquisa. Pelotas: Educat, 2012. p. 253-269. 
LISBOA; M. B.; PESSOA, S. Crítica ao novo-desenvolvimentismo. Cadernos do Desenvolvimento, Rio de Janeiro, v. 11, n. 19, p. 181-189, jul.-dez. 2016.

MARTINS, J. C.; SILVA, R. C. Da intervenção do Estado na economia. Revista do Curso de Direito da Faculdade de Humanidades e Direito, v. 8, n. 8, p. 9-30, 2011.

MARTINS, K. L. M. et al. A terminologia linguagem matemática no ensino da matemática: reflexão em tese do Programa de Pós-Graduação em Ciências e Matemática. Amazônia (UFPA), v. 15, n. 34, p. 200-2010, 2019.

MARTINS, W. R.; BARROS, T. H. B.; MORAES, J. B. E. Perspectivas discursivas na formação do conceito de descrição da informação em arquivística. Agora (Florianópolis), v. 29, n. 58, p. 113, jan./jun. 2019.

MEURER, J. L. Esboço de um modelo de produção de textos. In: MEURER, J. L.; MOTTA-ROTH, D. (Org.). Parâmetros de textualização. Santa Maria: Editora UFSM, 1997. p. 13-28.

MOREIRA, A. G.; AREND, M. Que estratégia de desenvolvimento seguir? O debate desenvolvimentista brasileiro no século XXI. Revista Análise Econômica, Porto Alegre, v. 34, n. 65, p. 205-239, mar. 2016. Disponível em: https://seer.ufrgs.br/AnaliseEconomica/article/view/47299/36643 Acesso em: 20 out. 2019.

ORLANDI, E. P. Análise de Discurso: princípios \& procedimentos. 8. ed. Campinas: Pontes, 2009.

PÊCHEUX, M. Sobre a (des-)construção das teorias lingüísticas. In: DRLAV, no 27, 1982, p. 124. Tradução brasileira de Celene M. Cruz e Clémence Jouët Pastré. In: Línguas e Instrumentos Linguísticos, Campinas, n. 2, 1999.

REVISTA ANÁLISE ECONÔMICA. Porto Alegre: FCE/UFRGS, 2015-2019. Quadrimestral. Disponível em: <www.ufrgs.br/rae>. Acesso em: 14 jan. 2020.

RIBEIRO, S. S. Os resumos produzidos no universo acadêmico. In: ENCONTRO NACIONAL DE CIÊNCIAS DA LINGUAGEM APLICADAS AO ENSINO, 2., 2003, João Pessoa. Anais... João Pessoa: UFPB, 2003. Disponível em:

http://www.leffa.pro.br/tela4/Textos/Textos/Anais/ECLAE_II/os\%20resumos\%20produzidos /principal.htm. Acesso em: 29 fev. 2020.

SANDRONI, P. (Org.). Dicionário de Economia do século XXI. 8. ed. Rio de Janeiro; São Paulo: Record, 2016.

SILVA A. P.; BARROS, T. H. B.; MORAES, J. B. E. O discurso da imparcialidade em códigos de ética do arquivista. Agora (Florianópolis), v. 28, n. 57, p. 213-226, 2018.

SKETCH ENGINE: Language corpus management and query system. Disponível em: <https://www.sketchengine.eu>. Acesso em: 23 jan. 2020. 
VARASCHIN, J. A. A. Os sentidos da ação estatal nos anos 1930: centralização política e intervencionismo na constituição de 1934. Revista Análise Econômica, Porto Alegre, v. 37, n. 74, p. 141-164, set. 2019. Disponível em: https://seer.ufrgs.br/AnaliseEconomica/article/view/77409/54387 Acesso em: 12 out. 2019. VASCONCELLOS, M. A. S.; GARCIA, M. E. Fundamentos de Economia. 5. ed. São Paulo: Saraiva, 2014. 